\title{
Характеристика основних біомаркерів ішемічного ураження м'язової тканини
}

\author{
Ірина Чорна, Олександр Мотузюк
}

Східноєвропейський університет імені Лесі Українки, Луцьк, Україна Адреса для листування: irynachorna24@gmail.com

Отримано: 13.05.19; прийнято до друку: 14.06.19; опубліковано: 28.06.19

Резюме. Ішемія становить основу патогенетичних механізмів гострих і хронічних захворювань серця й судин. Найвищу смертність спричинено саме ішемічною хворобою серця. Важливу роль у відповіді на ішемічне пошкодження відіграє активація низки кіназ, які встановлюють складні зв'язки між клітинами для досягнення біологічних ефектів. Через каскад реакцій, індукований кіназами, синтезуються та виділяються в кров'яне русло різні фактори білкової природи. Найбільш вивченими є натрійуретичні пептиди, кардіальні тропоніни, кінази, різні фактори росту. Вони використовуються як діагностичні маркери ушкодження міокарда. Найбільш точними маркерами вважаються натрійуретичні пептиди та кардіальні тропоніни. Проте на сьогодні важливе використання комплексу маркерів для більш точної діагностики ішемічного ураження. Концентрація цих білкових факторів зростає вже в перші години пошкодження й залежить від його ступеня. Деякі серед наведених білкових факторів не є специфічними до серцевої тканини та впливають також на скелетну мускулатуру. Систематизація літературних даних дає змогу зрозуміти основні ланки в механізмі дії цих факторів і їх впливу на ішемізовану тканину. Виявлені особливості $є$ актуальними для проведення подальших досліджень щодо впливу білкових факторів на параметри скорочення м'язової тканини.

Ключові слова: ішемія, натрійуретичний пептид, кардіальні тропоніни, h-FABP, креатинкіназа-MB, фактори росту, галектин-3, АМР-активована протеїнкіназа.

\section{The Characteristic of the Main Ischemic Damaging Biomarkers of Muscle Tissue}

\section{Iryna Chorna, Oleksandr Motuziuk}

Lesya Ukrainka Eastern European National University, Lutsk, Ukraine

Correspondence: irynachorna24@gmail.com

\begin{abstract}
The ischemia forms the basis of pathogenetic mechanisms acute and chronic heart diseases and blood vessels diseases. Ischemic heart disease causes the highest mortality. The activation a number of kinases playes an important role in establishing complex cells interconnections to achieve biological effects in the response to ischemic injury. Various protein nature factors are synthesized and isolated in the bloodstream owing to reactions cascade induced by kinases. The most studied are natriuretic peptides, cardiac troponins, and various growth factors. They are used as diagnostic markers of myocardial damage. The most accurate markers are natriuretic peptides and cardiac troponins. In particular, natriuretic peptides depress the renin-angiotensin and sympatho-adrenal system, and also have diuretic effects. Cardiac troponins are isolated exclusively from the myocardium. They are contained in structural and cytosolic pools. They play an important role in reducing $\mathrm{Ca} 2+$ sensitivity of force development. There is a number of less studied and significant protein factors that are released during ischemia. Due to its specificity, heart-fatty acid binding protein is the earliest diagnostic marker of myocardial ischemic injury. Creatine Kinase-MB has negative effects during excessive physical activity due to high interstitial fluid permeability. Stimulating growth factor is closely related to interleukin-33, which provides cardioprotective effect. The growth-differentiation factor-15 (GDF-15) is synthesized on the
\end{abstract}


myocardium cell membranes surface in response to ischemia-reperfusion. It is involved in the processes of myocardial recovery and fibrosis. The vascular endothelial growth factor stimulates the cellular response by binding to the appropriate receptors on the cellular muscle fiber membrane, in the sarcoplasm and the nuclear membranes of the ischemic muscle. Altogether with GDF-15, it protects the heart from ischemia-reperfusion injury by the signaling kinase path PI3K-Akt. Today the Fibroblast Growth Factor 23 is considered as a new risk factor for cardiovascular disease. It`s high level may be mediated by left ventricular hypertrophy. Galectin-3 transduces extracellular signal and participates in the processes of acute inflammatory reactions, cardiomyocytes repair, regulation of the apoptosis intensity. The AMP-activated protein kinase is an important regulator of the cellular response pathways in the energy stress conditions. It affects the degree of glucose absorption and glycolysis process. Nowadays, it is important to use a marker complexes for more accurate diagnosis of ischemic damage. The concentration of these protein factors increases in the first hours of damage and depends on damage severity. Some of the protein factors are not specific to the heart tissue and have an effect on skeletal muscle. The systematization of literary data allows us to understand the main links in the mechanism of these factors and what effect they have on the ischemic tissue. The revealed features will be relevant for further research of protein factors effects on the parameters of muscle contraction.

Key words: ischemia, natriuretic peptide, cardiac troponins, h-FABP, creatine kinase-MB, growth factors, Galectin-3, AMP-activated protein kinase.

\section{Ветуп}

Основну роль у формуванні патогенетичних механізмів гострих і хронічних захворювань серцево-судинної системи відіграє ішемія. Як свідчать дані [1], у США в період із 1996 по 2006 р. кількість госпіталізованих осіб у зв'язку 3 хронічною серцевою недостатністю досягла 1 млн. У 2008 одна 3 шести смертей була викликана ішемічною хворобою серця, а смертність становила 405 309. Водночас щорічно реєструються 195000 інфарктів міокарда, які виникають уперше [2]. Україна ж займає одне 3 перших місць у Свропі за показниками захворюваності та смертності від патологій, пов'язаних із серцево-судинною системою. Серед них найбільш поширена ішемічна хвороба серця, смертність від якої становить $71,1 \%$ [3].

У процесі діагностики серцевих патологій повинні об'єднуватися як клінічні ознаки (задишка, кашель, блідість, серцебиття, набряк нижніх кінцівок тощо), так і нейроендокринні маркери, оскільки у відповідь на ішемічне пошкодження синтезуються та активуються різні білкові фактори. Їх концентрація в крові може засвідчувати наявність чи відсутність, а також ступінь ішемічного пошкодження. Це дасть змогу більш точно обрати стратегію лікування та реабілітації пацієнтів [4].

Ішемічне ураження характерне також для поперечно-посмугованої мускулатури. Хірургічні процедури, оклюзійні пов'язки, переломи, сильні удари або реперфузійна травма можуть збільшити внутрішньо-клітинний тиск $\mathrm{i}$ зменшити васкуляризацію певної ділянки та, як наслідок, призвести до ішемізації кінцівки [5]. Згідно 3 даними, післяопераційна втрата кінцівок становить 10-30\%, а післяопераційна смертність 10-20\%, що є прямими наслідками важкої ішемічно-реперфузійної травми кінцівок [6]. Визначення точного ступеня ішемічного ураження має важливе клінічне значення. Реваскуляризація ішемізованої кінцівки може збільшити частоту виникнення ускладнень i смертність.

Унаслідок ішемічного ушкодження м'язової тканини у кров виділяться велика кількість білкових факторів, які опосередковують запальні процеси. Ці фактори виділяються через запуск каскадів біохімічних реакцій i впливають на протікання ішемії. Порівнюючи механізми їх впливу на м'язову тканину, можемо підібрати ефективні стратегії лікування та фармакологічні препарати для корекції, усунення наслідків i профілактики захворювань, ключовою ланкою яких є ішемія, що особливо актуально на сьогодні. На основі такого аналізу перспективним буде проведення подальших досліджень щодо впливу білкових факторів на параметри скорочення м'язової тканини.

Мета роботи - систематизація сучасних літературних даних щодо механізму впливу білкових факторів на ішемічні процеси в серцевій та скелетній мускулатурі.

\section{Біохімічний каскад ішемії}

Уважається, що в процесі ішемії захисні реакції організму здійснюються через вузький діапазон внутрішньоклітинних шляхів. Показано, що адаптація тканини до ішемічного ушкодження супроводжується активацією низки кіназ [7].

Ішемічне ушкодження являє собою складний каскад реакцій, який супроводжується перекисним окисленням ліпідів. У скелетних м'язах, за умов обмеженого доступу кисню, синтез зменшується АТФ і відбувається 
Характеристика основних біомаркерів ішемічного ураження м'язової тканини

перехід на анаеробний метаболізм. Міоцити починають виробляти молочну кислоту. Унаслідок різкої зміни внутрішньоклітинного $\mathrm{pH} \mathrm{Ca}^{2+}$ проникає всередину клітини у великих кількостях. Концентрація $\mathrm{Ca}^{2+}$ в цитозолі різко збільшується, що призводить до активації протеаз (наприклад ендонуклеаз, АТФаз, фосфоліпаз), які спроможні змінювати ксантиндегідрогеназу в ксантиноксидазу. Остання бере участь у перетворенні молекулярного кисню на супероксидні радикали під час реперфузії. Дія ферментів сприяє більшій проникності мембран клітин, за рахунок чого токсичні речовини потрапляють усередину клітини у великих кількостях, руйнуючи мітохондрії й продукуючи додаткові токсини та фактори. Ішемізований міоцит гине через некроз, вивільняючи токсичні речовини в міжклітинний простір. $\mathrm{У}$ відповідь на запальний процес активується каскад відповіді, формуючи набряк тканини $[8 ; 9 ; 10 ; 11]$.

Щодо серцевої тканини, то залежно від фізіологічного контексту, аспекти реактивної серцевої гіпертрофії можуть бути як корисними, так шкідливими. Молекулярні події (molecular events), які сигналізують про гіпертрофію мають багато паралельних i надлишкових трансдукторів й ефекторних шляхів. Білкові кінази та фосфатази, такі як мітоген-активована протеїнкіназа (МАРК), циклін-залежні кінази-9, кальцій/кальмодулінзалежні протеїнкінази, і кальмодулін-залежні фосфатази, $\epsilon$ найвивченішими медіаторами гіпертрофії [12].

У процесі підвищення стійкості міокарда до пошкоджень під час тривалого періоду ішеміїреперфузії (прекондиціонуванні) виділяється три етапи: тригерний - сприйняття сигналів, стадія внутрішньоклітинної передачі сигналу й стадія реалізації захисного механізму. Основою першого етапу є накопичення речовин-тригерів (наприклад адреналін, активні форми кисню, іони кальцію) унаслідок нетривалих послідовних епізодів ішемії. Вони запускають внутрішноклітинний каскад передачі сигналів. Наступна стадія забезпечується системою медіаторів - протеїнкіназ, тирозинкіназ, фосфатидилінозитол-3-кіназою (РІ3К), МАРК тощо. Далі відбувається активація мітохондріальних і сарколемних $K_{A T \Phi}$-каналів та NO-синтази. Активація сарколемних $K_{A T \Phi^{-}}$ каналів супроводжується зменшенням тривалості потенціалу дії i, як наслідок, послабленням внутрішньоклітинного перевантаження іонами кальцію. У процесі реперфузії на ранніх етапах пори, що регулюють проникність внутрішньої мембрани мітохондрій (мПРП), відкриваються. Активація кальцій-активованих калієвих каналів калієвими струмами призводить до часткової деполяризації мітохондріальної мембрани 3 подальшим зменшенням електричної рушійної сили іонів кальцію. Це спричиняє зниження кількості іонів кальцію всередині клітини під час

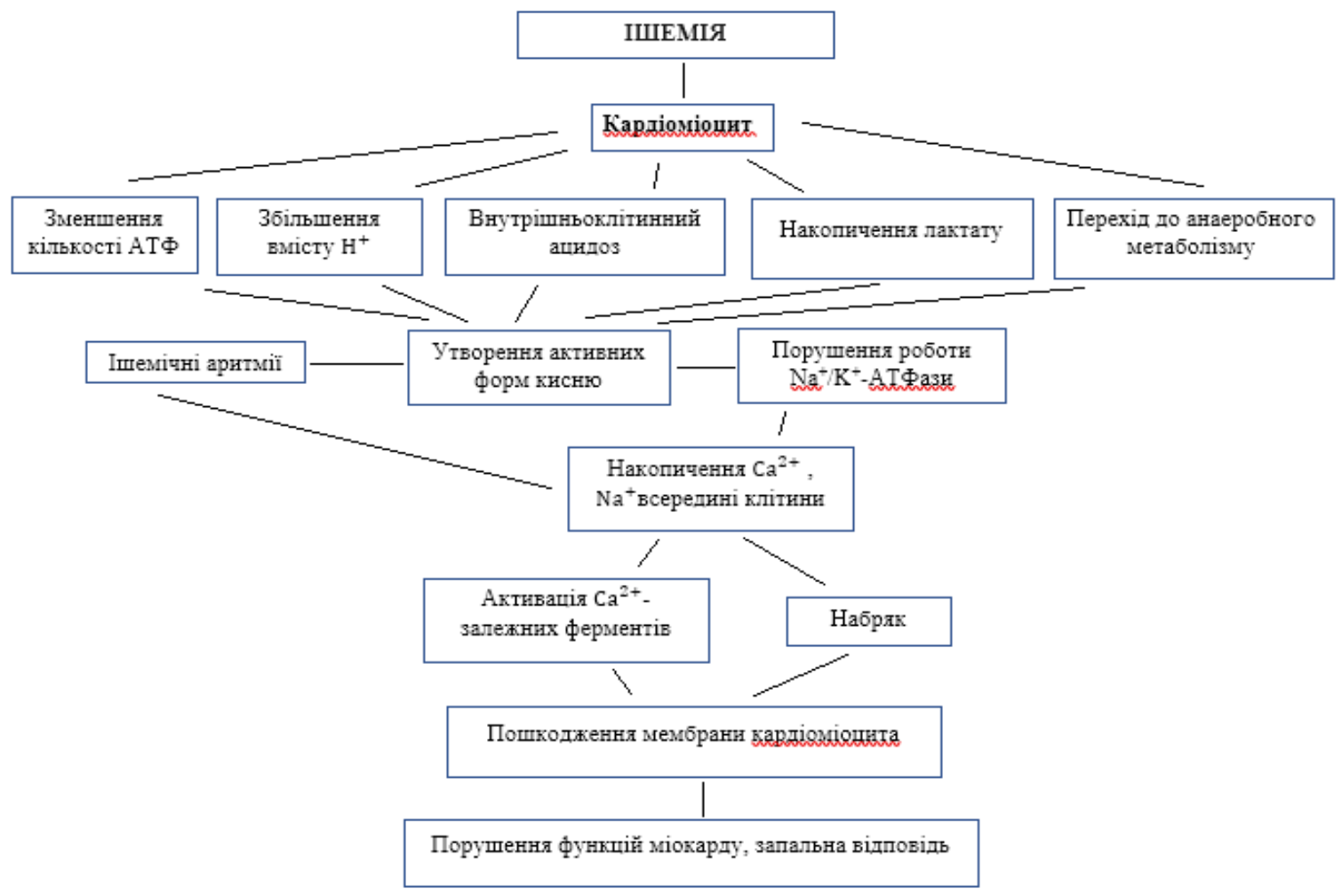

Рис. 1. Схема механізму розвитку ішемічного ураження міокарда 
ішемії, а також до загибелі клітин під час реперфузії. Це призводить до стрімкого набухання матриксу мітохондрій, зменшення синтезу АТФ та апоптозу. РІ3К, протеїнкіназа В (Akt), МАРК можуть інгібувати активність глікогенсинтази, підвищуючи поріг відкриття мПРП. Отже, захист міокарда під дією прекос- диціювання формується в результаті активації кількох механізмів, уключаючи відкриття $\mathrm{K}+-$ каналів внутрішньої мембрани мітохондрій i

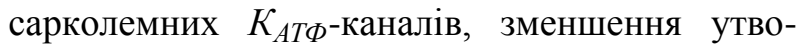
рення активних форм кисню в ході реперфузії, модуляцію метаболізму жирних кислот та інгібування мПРП [13; 14; 15; 16].

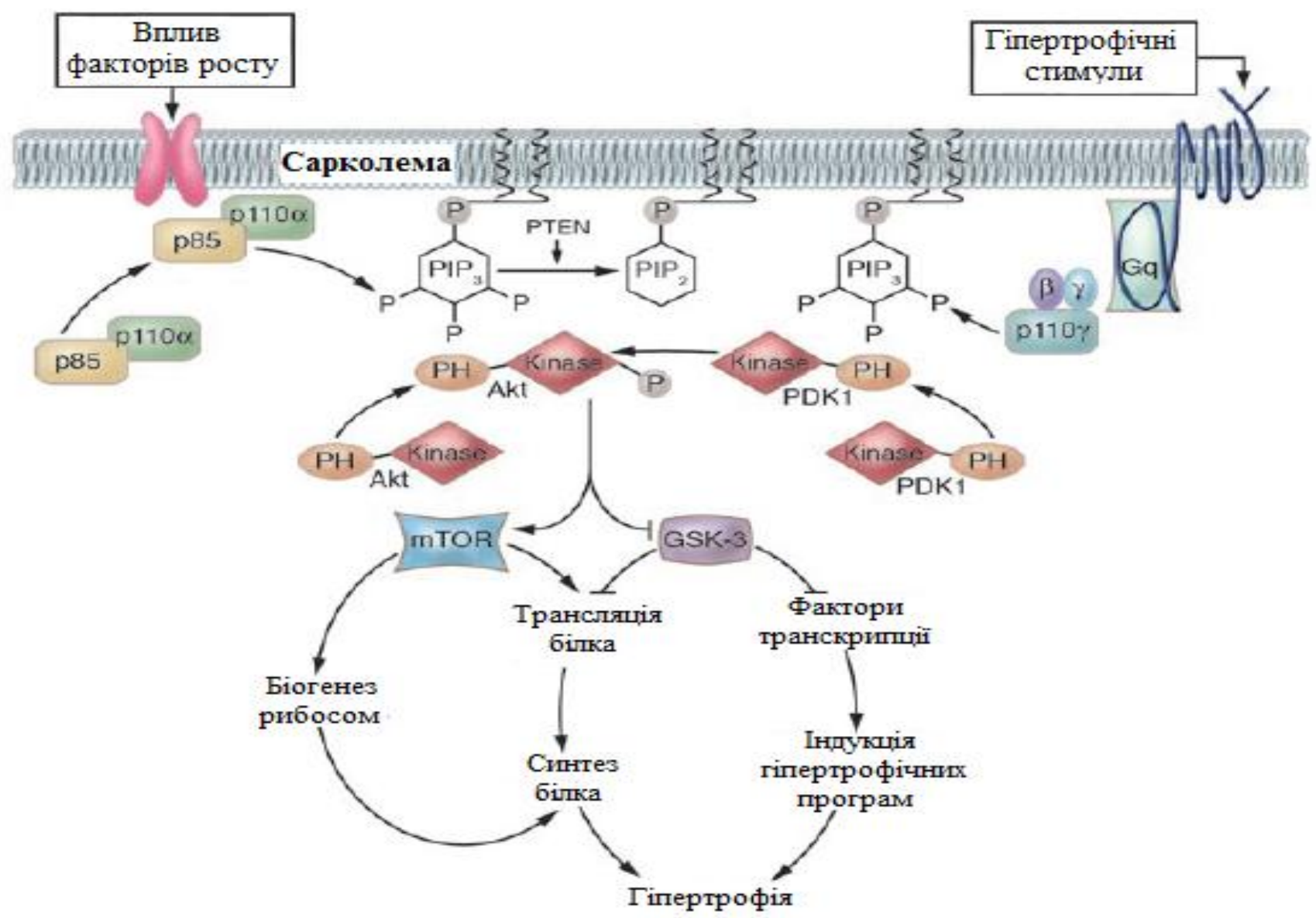

Рис. 2. Порівняння механізмів активації сигналізациї PI3K/Akt nid час адаптивної й патологічної zinepтрофiї [12]

Примітка. $У$ прочесі адаптивної гіпертрофії зв'язування факторів росту зі спорідненими

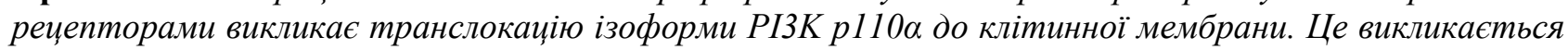
взаємодією субодиниці р85 PI3K із конкретними фосфорильованими залишками тирозину на

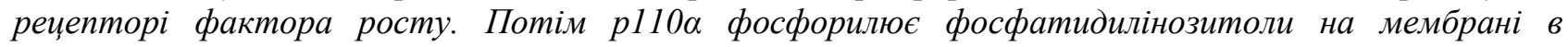
положенні 3'-інозитольного кільия. Домени гомології плекстрину (PH) обох Akt $i$ його активатора PDK1 асоціюють з 3 'фосфорильованими ліпідами, щуо дає змогу PDK1 активувати Аkt. Повна активачія Akt вимагає фосфорилювання іншою кіназою (не показана), яка може бути ДНКзалежною протеїнкіназою (DNA-PK). Активачія Akt призводить до активації иентрального регулятора синтезу білка (тTOR). Він впливає як на біогенез рибосом, так і на активацію механізму трансляиї білка. Akt також фосфорилює та інгібує глікогенсинтазу кіназу-3 (GSK-3, із яких є 2 ізоформи, $\alpha$ i $\beta$ ). Це сприяє як синтезу білка, так і транскрипиії генів. Патологічна гіпертрофія, викликана нейро-гормональними медіаторами й біомеханічним стресом, також активує Akt, але механізм уключає активацію гетеротримерних G-білкових рецепторів, пов'язаних із родиною $G$ -

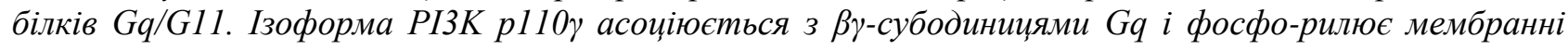
фосфатидилінозитоли, що призводить до набору PDK1 й Akt. Патологічна гіпертрофія також залучає альтернативні шляхи до активачї mTOR й Akt. Також показана фосфатаза, PTEN, яка за допомогою дефосфорилювання 3'-положення фосфатидилі-нозитолтрисфосфату (PIP3) зупиняє передачу сигналу цим иляхом. 
Протеїнкінази чинять свій біологічний ефект за допомогою внутрішньоклітинних меседжерів і подальшого субклітинного розподілу цих трансдукторів. Це дає змогу досягти об'єднання функцій клітин в організмі й установлення контакту з відповідними мішенями [17].

Серед сигнальних молекул існує родина протеїнкіназ, відомих як мітоген-активовані протеїнкінази (МАРК) кіназні модулі. МАРК являють собою серин-треонін-специфічні протеїнкінази. Вони становлять основу шляхів, що регулюють клітинну активність, а саме контролюють ембріогенез, диференціацію та пролізерацію клітин, апоптоз [8; 17]. Важливу роль у здійсненні їх біологічних ефектів відіграють рецепторні тирозинкінази. Вони фосфорилюють власні тирозини всередині клітин, що ініціюе запуск каскаду реакцій. Унаслідок цього мобілізується низка фосфоліпаз, що й призводить до активації МАРК [17].

Фізіологічна гіпертрофія серця опосередковується передачею сигналів через пептидні фактори росту: IGF-1 (інсуліноподібний фактор росту) і гормону росту (GH). Коли IGF-1, інсулін та інші фактори росту зв'язуються зі своїми мембранними рецепторами, активується ліпідна кіназа в ізоформі $\mathrm{I} \alpha$ (надалі - $\mathrm{p} 110 \alpha$ ), яка фосфорилює мембранний фосфоліпід фосфатидилінозитол 4,5-бісфосфат (PIP2). Це призводить до збільшення протеїнкінази Akt та її активатора, 3-фосфоінозитид-залежної протеїнкінази-1 (PDK1) на клітинній мембрані. Така колокалізація Akt i PDK1 призводить до того, що останні фосфорилюють й активують першу. Сигналізація PI3K/Akt забезпечує фізіологічну серцеву гіпертрофію [12].

У процесі патологічної гіпертрофії гетеротримерні G-білки Gq i G11 передають сигнали від фосфоліпази C, зв'язуючись із відповідними рецепторами до різних нейрогормонів (ангіотензину, ендотеліну, норепінефрину тощо). PI3K-залежна сигналізація в цьому випадку відрізняється від фізіологічної тим, що активується кіназна ізоформа $\gamma$ (p110 $\gamma)$, за допомогою поповнення сарколеми комплексом $\mathrm{Gq} / 11$, забезпечуючи доступ до мембранних фосфоінозитидів. Отже, сигналізація PI3K, у тому числі Akt, активується у відповідь як на фізіологічні, так і на патологічні стимули [12].

Цей каскад призводить до посилення взаємодії між клітинами крові й ендотелієм та постійного вивільнення токсичних речовин. Поряд із цим виділяються білкові фактори, які опосередковують негативні реакції в м'язовій тканині. У статті наведено найбільш вивчені з них.
Натрійуретичні пептиди (NP). Це група гормонів із подібною молекулярною структурою, які синтезуються клітинами лівого передсердя (передсердний натрійуретичний пептид - ANP) та лівого шлуночка (мозковий натрійуретичний пептид - BNP), а також клітинами центральної нервової системи (С-тип - CNP) [18]. ANP та BNP використовують циклічний гуанозинмонофосфат як внутрішньоклітинний меседжер для забезпечення ендокринної активності й здійснення їх фізіологічних ефектів: дилятація аферентних $\mathrm{i}$ констрикція еферентних гломерулярних артеріол, релаксація мезангіальних клітин, діурез, пригнічення секреції реніну й синтезу альдостерону, пригнічненя проліферації гладеньких м'язів судин, мезангіальних клітин, серцевих фібробластів, гіпертрофії кардіоміоцитів, ендохондральна осифікація, гіпотензивна дія, пригнічення секреції вазопресину та адренокортикотропного гормону [19]. Щодо $\mathrm{BNP}$, то він являе собою нейрогормон із діуретичними, судинорозширювальними й ренін-ангіотензивними антагоністичними ефектами. Цей пептид секретується клітинами шлуночків у відповідь на зростання систолічного об'єму та збільшення тиску на стінки шлуночків, а ішемія виступає одним 3 індукторів його вивільнення в кров'яне русло. BNP пригнічує секрецію реніну й синтез альдостерону, проліферацію серцевих фібробластів та має антигіпертрофічний ефект [20]. Через специфіку будови промоторної ділянки гена BNP цей пептид синтезується пулами прямо пропорційно до ступеня розширення шлуночка та збільшення тиску на його стінки $[19 ; 21]$. BNP синтезується у вигляді попередника, який надалі розщеплюється на С-термінальний власне BNP (біологічно активний) фрагмент, $\mathrm{N}$-кінцевий (NT-pro-BNP, неактивний) фрагмент [22].

Існують дані про маркерну інформативність рівнів BNP i NT-pro-BNP щодо дисфункції лівого шлуночка й ішемічного ураження міокарда [23]. Також можливе вивільнення BNP за умов відсутності дисфункції лівого шлуночка, під час тканинної гіпоксії. Підвищення рівня BNP стимулюється каскадом змін, які виникають у процесі зниження регіонального кровообігу міокарда. BNP, NTpro-BNP та ANP разом мають високу діагностичну точність і використовуються для діагностики та прогнозування протікання серцево-судинних захворювань.

Кардіальні тропоніни (сT). Існують два типи серцевих тропонінів: I (cTnI) і T (cTnT), що виділяються винятково 3 міокарда [24]. У 
міоцитах тропоніни містяться у двох пулах структурному (у міофібрилах) і цитозольному (у вільному від міофібрил стані, який виходить у кров під час раннього розвитку ушкоджень міокарда) [25]. Згідно з літературними даними, циркулюючі пули обох типів тропонінів $\epsilon$ рівнозначними під час діагностики та встановлення ступеня серцево-судинної травматизації внаслідок ішемії й навіть невеликі їх кількості можуть бути виявлені за рахунок високочутливих реагентів [26; 27; 28; 29]. Кардіотропонін С є $\mathrm{Ca}^{2+}$ зв'язуючою субодиницею комплексу тропонінів. Його взаємодія 3 іншими субодиницями $є$ центральною для регуляції скорочення скелетних i серцевих м'язів [30]. Кардіотропонін Т - це 37-кДа поліпептидна субодиниця міофібрилярного регуляторного тропонінового комплексу [31]. Збільшення рівня сТп може розглядатись лише як прояв травматизації міокарда, за відсутності інших ознак гострого інфаркту та не обов'язково $є$ проявом незворотних процесів Вивільнення сTn iз некротизованих кардіоміоцитів $€$ поступовим процесом. Загальна кількість вивільненого стn відповідає ступеню некрозу. Проте регенерація міоцитів відбувається протягом усього життя людини й прискорюється за умов систематичного виконання фізичних вправ. Відомо, що в тренованих спортсменів збільшення вмісту кардіотропонінів менш виражене [27].

Значне збільшення високочутливих кардіотропонінів, найімовірніше, сигналізує про недостатнє навантаження на організм [27; 32; 33]. Однак точні механізми вивільнення тропоніну 3 кардіоміоцитів та його виділення 3 кровообігу залишаються до кінця не визначеними. Підвищення концентрації тропоніну в плазмі найбільш корелює 3 підвищенням рівня натрійуретичних пептидів, наявністю цукрового діабету, пошкодженням судин i прогресуючою втратою кардіоміоцитів, а також зниженням швидкості ниркової фільтрації [34].

Серцевий білок, що зв'язус жирні кислоти (h-FABP) або серцевий жирно-кислотний зв'язуючий білок являє собою низькомолекулярний цитоплазматичний білок, який починає вивільнятися 3 міокарда протягом 30 хв від початку ушкодження. Вважається, що він $€$ першим діагностичним маркером для раннього виявлення міокардіального ушкодження, унаслідок своєї високочутливості й специфічності. Також він важливий для раннього встановлення діагнозу гострого інфаркту міокарда $[27 ; 35 ; 36]$. Рівень h-FABP у крові прямо залежить від розміру ушкодження міокарда [35]. Однак деякі дослідники стверджують про меншу точність прогнозування h-FABP під час діагностики гострого інфаркту міокарда, ніж тропоніну, унаслідок невідповідності й мінливості щодо чутливості й специфічності h-FABP [37].

\section{Креатинкіназа-MB (CK-MB)}

цитозольним білком-транспортером для високоенергетичних фосфатів [38]. Оскільки вона наявна у великих кількостях у скелетних м'язах і їі підвищений рівень виявляється під час низки патологічних станів, креатинкіназа не використовується як самостійний маркер для виявлення ушкодження міокарда [39]. СК у цитоплазмі має три ізоформи - CK-BB, CK-MB i CK-MМ, кожна 3 яких складається 3 двох субодиниць, названих відповідно до тканини, у якій їх уміст є переважаючим: В (brain - мозок) i M (muscule - скелетні м'язи, серцева тканина). Міокард містить 40 \% CKMB та 60 \% CK-MM разом зі слідами мітохондріальної СК [40]. Оскільки CK-MB міститься в найбільшій кількості в міокарді, то вона разом 3 іншими ізоформами використовується як біохімічний маркер у пацієнтів із підозрою на гострий інфаркт міокарда [39]. Щодо скелетних м'язів, то під час надмірних фізичних навантажень СК просочується в інтерстиціальну рідину й за допомогою лімфатичної системи повертається в циркуляцію, таким чином беручи участь у негативних ефектах [40].

Стимулюючий фактор росту (ST-2) експресується в міокарді за умов механічного перевантаження кардіоміоцитів і може існувати в розчинній та зв'язаній із мембраною формах [26; 41]. Згідно з М. Фелкером, механічне перенавантаження кардіоміоцитів зумовлює підвищення рівня ST2. Також механічне розтягнення кардіоміоцитів може посилювати вивільнення інтерлейкінів-33 (IL-33) із цитоплазматичних везикул. Зі свого боку, IL-33 блокує дію ангіотензину II на міокард, підвищуючи антигіпертрофічний ефект. Це викликає гіпертрофію кардіоміоцитів, активність фібробластів та апоптоз [42]. Вважається, що саме розчинна форма ST2 може зв'язувати IL-33. Сигналізація IL-33 через трансмембранний рецептор ST2L забезпечує кардіопротекторну дію від надлишкового стресового навантаження [41].

Фактор росту та диференціювання-15 (GDF-15) належить до надродини цитокінів трансформуючих факторів росту бета (TGF-b). Він синтезується на поверхні мембран клітин міокарда у формі попередника pro-GDF-15 у відповідь на ішемію-реперфузію та інші 
Характеристика основних біомаркерів ішемічного ураження м'язової тканини

запальні процеси [26; 43]. Деякі науковці вважають, що ранній приріст циркулюючого рівня GDF-15 може бути пов'язаний із його підвищеним синтезом у перші години інфаркту міокарда й, імовірно, вивільненням GDF-15 із позаклітинного запасу саме pro-GDF-15 [43; 44]. GDF-15 здійснює виражений антигіпертрофічний ефект за участю кіназного , бере участь у процесах відновлення міокарда, фіброзу [45; 46; 47]. Також використовують комбінацію GDF-15 та NT-pro-BNP, що підвищує прогностичну цінність кожного 3 біомаркерів [48].

Фактор росту ендотелію судин (VEGF) або васкулоендотеліальний фактор росту стимулює клітинну відповідь, зв'язуючись із VEGFрецепторами, локалізованими на клітинній мембрані, у саркоплазмі та ядерних оболонках ішемізованих м'язових волокон [49]. За умови дефіциту кисню клітина виробляє індукований гіпоксією фактор транскрипції (HIF), який стимулює вивільнення білків VEGF. Далі VEGF зв'язується 3 VEGF-рецептором на клітинах ендотелію й активує дію тирозинкінази, запускаючи ангіогенез. Зниження концентрації цього фактора пов'язане 3 наявністю цукрового діабету [50].

Разом iз GDF-15 фактор росту ендотелію судин захищає серце від пошкодження внаслідок ішемії-реперфузії за допомогою сигнального кіназного шляху PI3K-Akt [45]. Уміст VEGF збільшується в стабільній фазі після інфаркту міокарда й корелює 3 рівнем запальних цитокінів. Здатність VEGF ініціювати ріст судин дає підставу розглядати його в перспективі як засіб для покращення васкуляризації міокарда. Високі концентрації цього фактора мають позитивний вплив на процес колагеноутворення в зонах постінфарктного кадріосклерозу [51].

Фактор росту фібробластів 23 (FGF-23) це гормон, який уперше був описаний як патогенний фактор у рідкісних гіпофосфатемічних синдромах. Він підвищує швидкість виділення фосфату із сечею й пригнічує продукцію 1,25-дигідроксивітаміну $\mathrm{D}$, полегшуючи гіперфосфатемію в пацієнтів із захворюванням нирок. Проте його можна розглядати, як новий фактор ризику серцевосудинних захворювань [52]. Припускається, що FGF-23 є не просто біомаркером серцевосудинного ризику, а швидше - новим молекулярним медіатором під час травматизації серцевої тканини [53]. Високі та помірні концентрації FGF-23 у плазмі свідчать про схильність до виникнення серцево-судинних захворювань [54]. Уважається, що підвищений рівень FGF-23 пов'язаний із виявленими значними концентраціями кардіального тропоніну й може бути опосередкований гіпертрофією лівого шлуночка [53].

Галектин-3 (Gal-3) належить до родини лектинів і являє собою 29-35кДа $\beta$-галактозидзв'язуючий білок. Уважається, що він складається $з$ двох доменів: нетипового N-кінцевого домену та С-кінцевого домену розпізнавання вуглеводів (CRD) і являє собою інтегральний білок. Згідно 3 літературою [26], галектин-3 може переміщуватись із цитоплазми до ядра, що зумовлює індукцію проліферації клітин та їх органел. Він зв'язується на поверхні клітин антигенів із їхніми рецепторами, формуючи ліпополісахаридний комплекс і таким чином передає позаклітинний сигнал. Gal-3 вивільняється під час диференціювання моноцитів у макрофаги й бере участь у процесах гострих запальних реакцій, таких як активація та адгезія нейтрофілів, хемоатракція моноцитів, опсонізація апоптотичних нейтрофілів й активація базофілів. Припускають, що Gal-3 бере участь у процесах відновлення кардіоміоцитів, забезпечуючи взаємодію трансформуючого фактора росту- $\beta$, інтерферону- $\gamma$, ангіотензину- 2 та альдостерону. Існують дані щодо здатності Gal-3 активувати фібробласти, міофібробласти й макрофаги, цим самим регулюючи інтенсивність апоптозу та накопичення міжклітинної речовини в різних тканинах. Також Gal-3 бере участь у гліколізації внутрішньоклітинних протеїнів [41; 55; 56]. Галектин-3 і ST-2 відображають ступінь пошкодження тканин, незалежно від умов навантаження на серце. Вони можуть доповнювати інші біомаркери, що використовуються на сьогодні [41]. Gal-3 є більш потужним прогностичним параметром несприятливого прогнозу в пацієнтів зі встановленим діагнозом серцевої недостатності [57].

АМР-активована протеїнкіназа (АМРК) є важливим регулятором різноманітних клітинних шляхів в умовах енергетичного стресу. Згідно $з$ дослідженням Р. Рассела та Р. Бергерона, утрата активності АМРК у серцевій тканині миші пов'язана 3 нездатністю збільшувати поглинання глюкози й процеси гліколізу.

На це впливає також ступінь некрозу під час ішемії $з$ повільним протіканням. Крім того, утрата активності АМРК має важливі функціональні наслідки в реперфузованому постішемічному серці, такі як сповільнення відновлення скорочувальної функції лівого шлуночка, що пов'язано 3 низьким вмістом АТФ, збільшення некрозу та апоптичної активності. Ці результати показують, що 
АМРК має важливу кардіопротекторну дію в ішемізованому серці [58; 59]. Утрата активності AMPK інгібує стимульоване гіпоксією поглинання глюкози в скелетних м'язах [60]. Хоча для підтримки нормальної кількості транспортерів глюкози (GLUT-4) в м'язі висока активність АМРК не $є$ необхідною. Дослідження також демонструють знижену продукцію лактату під час повільно протікаючої ішемії та реперфузії в серці, що частково $є$ наслідком зменшення транспорту глюкози. Відомо, що АМРК фосфорилює й активує 6-фосфофрукто-2-кіназу (PFK-2) під час ішемії. Відсутність активації РFК-2 може сприяти зниженню гліколітичного потоку та продукування лактату [61].

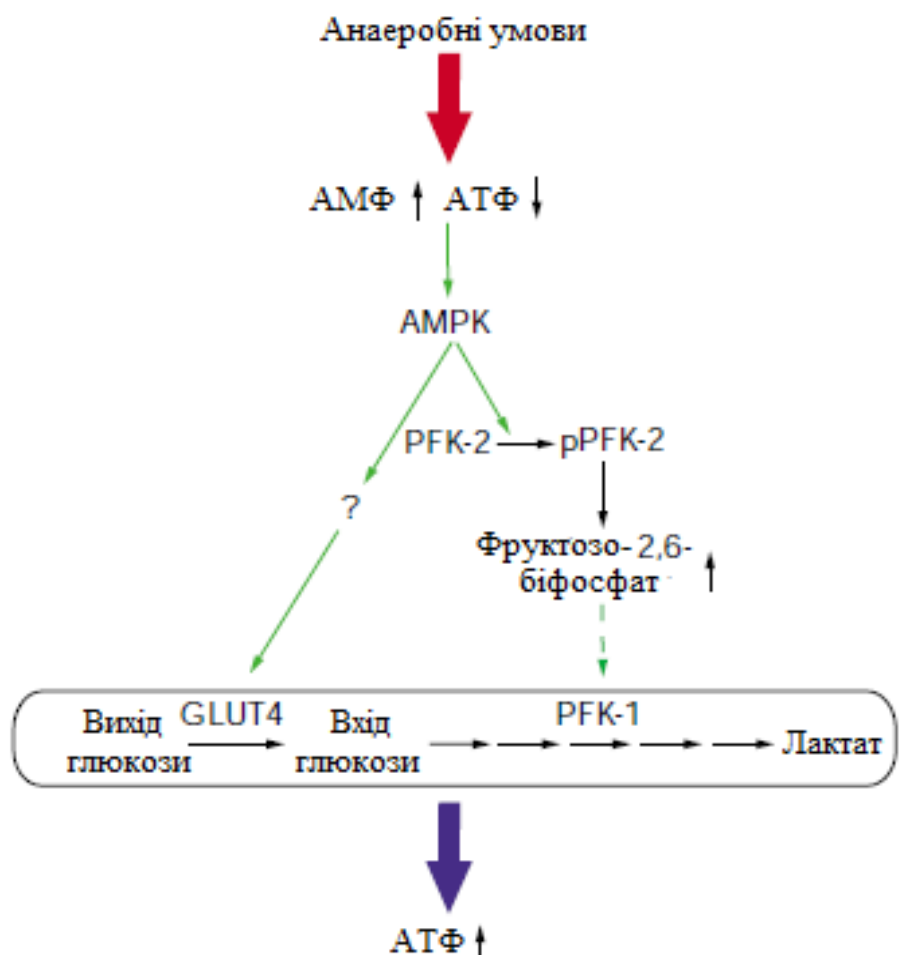

Рис. 3. Механізм стимуляції серцеевого гліколізу АМРК в анаеробних умовах [61]

Примітка. Зелена стрілка, активація ковалентною модифікацією; пунктирна зелена стрілка, алостерична стимуляція; рPFК-2 - фосфорильована форма сериевої РFК-2. Знак запитання вказує на непрямий механізм, PFK-1 - фосфофруктокіназа-1.

\section{Висновки}

Отже, ішемічне ураження м'язової тканини призводить до виділення речовин, які запускають низку сигнальних каскадів. Це індукує синтез ендогенних білкових факторів, які опосередковують цей процес. Серед них найважливішими $\epsilon$ натрійуретичні пептиди, кардіальні тропоніни, серцевий білок, що зв'язує жирні кислоти, кінази, фактори росту та лектини. Їхні механізми зводяться до зв'язування 3 рецепторами на мембрані клітини-мішені, використання внутрішньоклітинних меседжерів для здійснення ефектів на ішемізовану тканину. Їх кількість у циркулюючому кров'яному руслі залежить від ступеня ішемічного ураження. Частина білкових факторів не $\epsilon$ специфічними щодо серцевої тканини й чинять несприятливі ефекти на скелетну мускулатуру під час ішемії.
Описані білкові фактори мають високу діагностичну та прогностичну значимість. Згідно 3 проаналізованими джерелами, відбувається проведення подальших досліджень щодо впливу білкових факторів на параметри скорочення м'язової тканини. Виявлені особливості можуть стати підгрунтям для підбору фармакологічних препаратів щодо корекції та лікування захворювань, ключовою ланкою яких $є$ ішемія.

\section{Література}

1. Lloyd-Jones, D. M.; Adams, R. J.; Brown, T. M.; et all. Executive summary: heart disease and stroke statistics - 2010 update: a report from the American Heart Association. Circulation; 2010, 121, pp 948-954. doi: 10.1161/CIRCULATIONAHA.109.1926.

2. Roger, V. L.; Go, A. S.; Lloyd-Jones, D. M.; et all. Executive summary: heart disease and stroke statistics - 2012 update: a report from the American 
Характеристика основних біомаркерів ішемічного ураження м'язової тканини

Heart Association. Circulation; 2012, 125, pp 188-197. doi: 10.1161/CIR.0b013e3182456d46.

3. Гандзюк, В. А. Аналіз захворюваності на ішемічну хворобу серця в Україні. Український кардіологічний журнал; 2014, 3, с 45-52.

4. Zannad, F.; Agrinier, N.; Alla F. Heart failure burden and therapy. EP Europace; 2009, 11 (5), pp 5159. doi:10.1093/europace/eup304.

5. Murdock, M.; Murdoch, M. M. Compartment syndrome: a review of the literature. Clinics in podiatric medicine and surgery; 2012, 29 (2), pp 301-310. doi: 10.1016/j.cpm.2012.02.001.

6. Turóczi, Z.; Arányi, P.; Lukáts, Á.; Garbaisz, D.; Lotz, G.; Harsányi, L.; Szijártó, A ${ }^{1}$. Muscle fiber viability, a novel method for the fast detection of ischemic muscle injury in rats. PLoS One; 2014, 9 (1), pp e84783. doi: 10.1371/journal. pone. 0084783 .

7. Шурыгина, И. А.; Шурыгин, М. Г. Изменение активности внутриклеточных сигнальных каскадов при ишемии. Международный журнал прикладных и фундаментальных исследований; 2016, 10, c 567-571.

8. Erkut, B.; Özyazıcıoğlu, A.; Karapolat, B. S.; Koçoğulları C. U.; Keles S.; Ateş A.; Gundogdu C.; Kocak H. Effects of ascorbic acid, alpha-tocopherol and allopurinol on ischemia-reperfusion injury in rabbit skeletal muscle: an experimental study. Drug target insights; 2007, 2, pp 2489-258.

9. Зай, С. Ю.; Заводовський, Д. О.; Богуцька, К. І.; Ноздренко, Д. М. .; Прилуцький, Ю. І. Перспективи застосування С60-фулерену як засобу профілактики i корекції ішемічно-репер-фузійних порушень у скелетній м'язовій тканині. Фізіологічний журнал; 2016, 62 (3), с 66-77.

10. Tidball J. G. Mechanisms of muscle injury, repair, and regeneration. Comprehensive Physiology; 2011, 1 (4), pp 2029-2062. doi: 10.1002/cphy.c100092.

11. Rácz, I. B.; Illyés, G.; Sarkadi, L.; Hamar, J. The functional and morphological damage of ischemic reperfused skeletal muscle. European Surgical Research; 1997, 29 (4), pp :254-263. doi: 10.1159/000129531.

12. Dorn, G. W.; Force T. Protein kinase cascades in the regulation of cardiac hypertrophy. The Journal of Clinical Investigation; 2005, 115 (3), pp 527-537. doi: 10.1172/JCI200524178.

13. Мохорт, М. А., Кутовий, Ю. М. Прекондиціювання міокарда (огляд літератури). Журнал Наиіональної академії медичних наук України; 2014, 20 (2), с 160-171.

14. Лупанов, В. П.; Максименко, А. В. Протективная ишемия в кардиологии. Формы кондиционирования миокарда. Кардиоваскулярная терапия и профилактика; 2011, 10 (1), с 96-103.

15. Testai, L.; Martelli, A.; Marino, A.; D'Antongiovanni, V.; Ciregia, F.; Giusti ,L.; Lucacchini, A.; Chericoni, S.; Breschi, M. C.; Calderone, V. The activation of mitochondrial BK potassium channels contributes to the protective effects of naringenin against myocardial ischemia/reperfusion injury. Biochemical pharmacology; 2013, 85 (11), pp 1634-1643. doi: 10.1016/j.bcp.2013.03.018.
16. Granfeldt, A.; Lefer, D. J.; Vinten-Johansen, J. Protective ischaemia in patients: preconditioning and postconditioning. Cardiovascular Research; 2009, 83 (2), pp 234-246. doi: 10.1093/cvr/cvp129.

17. Pearson, G.; Robinson, F.; Beers Gibson, T.; Xu, B.; Karandikar, M.; Berman, K.; Cobb, H., M. Mitogen-activated protein (MAP) kinase pathways: regulation and physiological functions. Endocrine reviews; 2001, 22 (2), pp 153-183. doi: 10.1210/edrv.22.2.0428.

18. Luchner, A.; Stevens, T. L.; Borgeson, D. D.; Redfield, M.; Wei, C. M.; Porter, J. G.; Burnett, J. C. Jr. Differential atrial and ventricular expression of myocardial BNP during evolution of heart failure. The American journal of physiology; 1998, 274 (5), pp 1684-1698. doi: 10.1152/ajpheart.1998.274. 5.H1684.

19. Бесага, Є. М. Визначення вмісту натрійуретичних пептидів у плазмі крові як діагностичний та прогностичний маркер при серцевій недостатності. Актуальні діагностичні підходи; 2009, 1. с 12-17.

20. Foote, R. S.; Pearlman, J. D.; Siegel, A. H.; Yeo, K. T. Detection of exercise-induced ischemia by changes in B-type natriuretic peptides. Journal of the American college of cardiology; 2004, 44 (10), pp 1980-1987. doi: 10.1016/j.jacc.2004.08.045.

21. Maisel, A. S.; Krishnaswamy, P.; Nowak, R. M.; et all. Rapid measurement of B-type natriuretic peptide in the emergency diagnosis of heart failure. The New England journal of medicine; 2002, 347 (3), pp 161-167. doi: 10.1056/NEJMoa020233.

22. Savarese, G.; Musella, F.; D'Amore, C.; Vassallo, E.; Losco, T.; Gambardella, F.; Cecere, M.; Petraglia, L.; Pagano, G.; Fimiani, L.; Rengo, G.; Leosco, D.; Trimarco, B.; Perrone-Filardi, P. Changes of natriuretic peptides predict hospital admissions in patients with chronic heart failure: a meta-analysis. JACC: heart failure; 2014, 2 (2), pp 148-158. doi: 10.1016/j.jchf.2013.11.007.

23. Savarese, G.; Trimarco, B.; Dellegrottaglie, S.; Prastaro, M.; Gambardella, F.; Rengo, G.; Leosco, D.; Perrone-Filardi, P. Natriuretic peptide-guided therapy in chronic heart failure: a meta-analysis of 2,686 patients in 12 randomized trials. PLoS One; 2013, 8 (3), pp 58287. doi: 10.1371/journal.pone.005828.

24. Apple, F. S.; Jesse, R. L.; Newby, L. K.; et all. National Academy of clinical biochemistry and IFCC Committee for standardization of markers of cardiac damage laboratory medicine practice guidelines: analytical issues for biochemical markers of acute coronary syndromes. Clinical chemistry; 2007, 53 (4), pp 547-551. doi: 10.1373/clinchem.2006. 084715.

25. Дорошенко, О. В. Значення підвищеного тропоніну у клінічній практиці. Проблеми екологічної та медичної генетики $i$ клінічної імунологї̈; 2013, 3, с 111-121.

26. Ханюков, О. О.; Сапожниченко, Л. В. Місце біомаркерів у діагностиці, стратифікації ризику та прогнозуванні серцевої недостатності. Медичні перспективи; 2018, 23 (2), с 56-63. doi: 10.26641/2307-0404.2018.2(part1).129517. 
27. Janota, T. Biochemical markers in the diagnosis of myocardial infarction. Cos et vasa; 2014, 56 (4), pp 304-310. doi: 10.1016/j.crvasa.2014.06.007.

28. Alehagen. U.; Dahlström. U.; Rehfeld, J. F.; Goetze J. P. Prognostic assessment of elderly patients with symptoms of heart failure by combining highsensitivity troponin $\mathrm{T}$ and $\mathrm{N}$-terminal pro-B-type natriuretic peptide measurements. Clinical chemistry; 2010, 56 (11), pp 1718-1724. doi: 10.1373/clinchem. 2009.141341.

29. Latini. R.; Masson, S.; Anand, I. S.; Missov, E.; Carlson, M.; Vago. T.; Angelici. L.; Barlera. S.; Parrinello. G.; Maggioni, A. P.; Tognoni. G.; Cohn, J. N. Prognostic value of very low plasma concentrations of troponin $\mathrm{T}$ in patients with stable chronic heart failure. Circulation; 2007, 116 (11), pp 1242-1249. doi: 10.1161/CIRCULATIONAHA. 106.655076 .

30. Gomes, A. V.; Potter, J. D.; Szczesna-Cordary $\mathrm{D}$. The role of troponins in muscle contraction. IUBMB Life; 2002, 54 (6) pp 323-333. doi: 10.1080/15216540.

31. Gerhardt, W.; Katus, H.; Ravkilde, J.; Hamm, C.; Jørgensen, P. J.; Peheim, E.; Ljungdahl, L.; Löfdahl, P. S-troponin $\mathrm{T}$ in suspected ischemic myocardial injury compared with mass and catalytic concentrations of S-creatine kinase isoenzyme MB. Clinical chemistry; 1991, 37 (8), pp 1405-1411.

32. Thygesen, K.; Mair, J.; Katus, H.; Plebani, M.; Venge, P.; Collinson, P.; Lindahl, B.; Giannitsis. E.; Hasin, Y.; Galvani, M.; Tubaro, M.; Alpert, J. S.; Biasucci, L. M.; Koenig, W.; Mueller, C.; Huber, K.; Hamm, C.; Jaffe, A. S. Recommendations for the use of cardiac troponin measurement in acute cardiac care. European heart journal; 2010, 31 (18), pp 2197-2206. doi: 10.1093/eurheartj/ehq251.

33. White, H. D. Pathobiology of troponin elevations: do elevations occur with myocardial ischemia as well as necrosis? Journal of the American college of cardiology; 2011, 57 (24), pp 2406-2408. doi:10.1016/j.jacc.2011.01.029.

34. Masson, S.; Anand, I.; Favero, C.; Barlera, S.; Vago, T.; Bertocchi, F.; Maggioni, A. P.; Tavazzi, L.; Tognoni, G.; Cohn, J. N.; Latini, R. Serial measurement of cardiac troponin $\mathrm{T}$ using a highly sensitive assay in patients with chronic heart failure: data from 2 large randomized clinical trials. Circulation; 2012, 125 (2), pp 280-288. doi: 10.1161/CIRCULATIONAHA. 111.044149 .

35. Charpentier, S.; Maupas-Schwalm, F.; Cournot, M.; Elbaz. M.; Ducassé, J. L.; Bottela, J. M.; Lauque, D. Diagnostic accuracy of quantitative heart-fatty acid binding protein assays compared with Cardiodetect( $\left({ }^{\circ}\right)$ in the early detection of acute coronary syndrome. Archives of cardiovascular disease; 2011, 104 (10), pp 524-529. doi: 10.1016/ j.acvd.2011.07.002.

36. Seino, Y.; Tomita, Y.; Takano, T.; Ohbayashi, K. Office cardiologists cooperative study on whole blood rapid panel tests in patients with suspicious acute myocardial infarction: comparison between hearttype fatty acid-binding protein and troponin $\mathrm{T}$ tests. Circulation journal; 2004, 68 (2), pp 144-148.
37. Rosman, J.; Kavala, G.; Obunai, K.; Bergmann $\mathrm{S}$. R. The role of heart-type fatty acid-binding protein in the diagnosis of acute coronary syndrome. International journal of angiology; 2009, 18 (2), pp 79-81.

38. Jaffe, A. S.; Babuin, L.; Apple, F. S. Biomarkers in acute cardiac disease: the present and the future. Journal of the American college of cardiology; 2006, 48 (1), pp 1-11. doi: 10.1016/j.jacc.2006.02.056.

39. Nigam. P. K. Biochemical markers of myocardial injury. Indian journal of clinical biochemistry; 2007, 22 (1) pp 10-17. doi: 10.1007/BF02912874.

40. Brancaccio, P.; Maffulli, N.; Limongelli, F. M. Creatine kinase monitoring in sport medicine. British medical bulletin; 2007, 81-82, pp 209-230. doi: 10.1093/bmb/ldm014.

41. Meijers, W. C.; van der Velde, A. R.; de Boer, R. A. ST2 and Galectin-3: Ready for prime time? The journal of International Federation of clinical chemistry and laboratory medicine; 2016, 27 (3), pp 238-252.

42. Felker, G. M.; Fiuzat, M.; Thompson, V.; Shaw, L. K.; Neely, M. L.; Adams, K. F.; Whellan, D. J.; Donahue, M. P.; Ahmad, T.; Kitzman, D. W.; Piña, I. L.; Zannad, F.; Kraus, W. E.; O'Connor, C. M. Soluble ST2 in ambulatory patients with heart failure: association with functional capacity and long-term outcomes. Circulation. Heart failure; 2013, 6 (6), pp 1172-1179. doi: 10.1161/CIRCHEAR TFAILURE.113.000207.

43. Kempf, T.; Björklund, E.; Olofsson, S.; Lindahl, B.; Allhoff, T.; Peter, T.; Tongers, J.; Wollert, K. C.; Wallentin, L. Growth-differentiation factor-15 improves risk stratification in ST-segment elevation myocardial infarction. European heart journal; 2007, 28 (23), pp 2858-2865. doi:10.1093/eurheartj/ehm465.

44. Annes, J. P.; Munger, J. S.; Rifkin, D. B. Making sense of latent TGFbeta activation. Journal of cell science; 2003, 116 (2), pp 217-224. doi: $10.1242 /$ jcs.00229.

45. Kempf, T.; Eden, M.; Strelau, J.; Naguib, M.; Willenbockel, C.; Tongers, J.; Heineke, J.; Kotlarz, D.; Xu, J.; Molkentin, J. D.; Niessen, H. W.; Drexler, H.; Wollert, K. C. The transforming growth factor-beta superfamily member growth-differentiation factor-15 protects the heart from ischemia/reperfusion injury. Circulation research; 2006, 98 (3), pp 351-360. doi: 10.1161/01.RES.0000202805.73038.48.

46. Dimmeler, S.; Zeiher, A. M. Akt takes center stage in angiogenesis signaling. Circulation research; 2000, 86 (1), pp 4-5.

47. Cheng, Y.; Jiang, S.; Hu, R.; Lv, L. Potential mechanism for endothelial progenitor cell therapy in acute myocardial infarction: activation of VEGFPI3K/Akt-eNOS pathway. Annals of clinical and laboratory science; 2013, 43 (4), pp 395-401.

48. Сиволап, В. Д.; Земляний, Я. В. Прогностичне значення рівнів GDF 15 і NTproBNP та ехокардіографічних показників у хворих на серцеву недостатність зі збереженою фракцією викиду та безсимптомну діастолічну дисфункцію, 
які перенесли інфаркт міокарда на тлі артеріальної гіпертензії. Запорожский медицинский журнал; 2014, 3 (84), c 13-17.

49. Шкуропат, В. М. Вплив аутотрансплантації аспірата кісткового мозку на рівень експресії VEGF в ішемізованому м'язі та концентрацію VEGF у крові хворих з хронічною ішемією нижньої кінцівки III ступеня у різних вікових групах. Морфологія; 2009, 3 (4), с 93-101.

50. Могильницька, Л. А. Васкулоендотуліальний фактор росту та ендотейлійзалежна дилатація у хворих 3 дитинства на цукровий діабет 1 типу 3 мікроангіопатіями та в осіб молодого віку 3 ожирінням. Клінічна ендокринологія та ендокринна хірургія; 2015, 3 (51), с 23-29.

51. Шурыгин, М. Г.; Шурыгина, И. А.; Дремина, Н. Н. Влияние фактора роста эндотелия сосудов на уровень коллагенообразования в процессе развития постинфарктного кардиосклероза. Сибирский медищинский журнал; 2008, 3, с 53-55.

52. Gutiérrez, O. M.; Mannstadt, M.; Isakova, T.; Rauh-Hain, J. A.; Tamez, H.; Shah, A.; Smith, K.; Lee, H.; Thadhani, R.; Jüppner, H.; Wolf, M. Fibroblast growth factor 23 and mortality among patients undergoing hemodialysis. The New England journal of medicine; 2008, 359 (6), pp 584592. doi: 10.1056/NEJMoa0706130.

53. Smith, K.; deFilippi, C.; Isakova, T.; Gutiérrez, O. M.; Laliberte, K.; Seliger, S.; Kelley, W.; Duh, Sh.-H.; Hise, M.; Christenson, R.; Wolf, M.; Januzzi, J. Fibroblast Growth Factor 23, HighSensitivity Cardiac Troponin, and Left Ventricular Hypertrophy in CKD. American journal of kidney diseases; 2013, 61 (1), pp 67-73. doi: 10.1053/j.ajkd.2012.06.022.

54. Kendrick. J.; Cheung, A. K.; Kaufman, J. S.; Greene, T.; Roberts, W. L.; Smits, G.; Chonchol, M.; HOST Investigators. FGF-23 associates with death, cardiovascular events, and initiation of chronic dialysis. Journal of the American society of nephrology; 2011, 22 (10), pp 1913-1922. doi: 10.1681/ASN.2010121224.

55. Amin, H. Z.; Amin, L. Z.; Wijaya, I. P. Galectin-3: a novel biomarker for the prognosis of heart failure. Clujul Medical; 2017, 90 (2), pp 129-132. doi: 10.15386/cjmed-751.

56. Lopez-Andrès, N.; Rossignol, P.; Iraqi, W.; Fay, R.; Nuée, J.; Ghio, S.; Cleland, J. G.; Zannad, F.; Lacolley, P. Association of galectin-3 and fibrosis markers with long-term cardiovascular outcomes in patients with heart failure, left ventricular dysfunction, and dyssynchrony: insights from the CARE-HF (cardiac resynchronization in heart failure) trial. European journal of heart failure; 2012, 14 (1), pp 74-81. doi: 10.1093/eurjhf/hfr151.

57. van der Velde, A. R.; Gullestad, L.; Ueland, T.; Aukrust, P.; Guo, Y.; Adourian, A.; Muntendam, P.; van Veldhuisen, D. J.; de Boer, R. A. Prognostic value of changes in galectin-3 levels over time in patients with heart failure: data from CORONA and COACH. Circulation. Heart failure; 2013, 6 (2), pp 219-226. doi: 10.1161/CIRCHEARTFAILURE.112. 000129.

58. Russell, R. R.; Bergeron. R.; Shulman, G. I.; Young, L. H. Translocation of myocardial GLUT-4 and increased glucose uptake through activation of AMPK by AICAR. The American journal of physiology; 1999, 277 (2), pp 643-649. doi: 10.1152/ajpheart. 1999.277.2.H643.

59. Russell ,R. R.; Li J.; Coven, D. L.; Pypaert, M.; Zechner, C.; Palmeri. M.; Giordano, F. J.; Mu, J.; Birnbaum, M. J.; Young, L. H. AMP-activated protein kinase mediates ischemic glucose uptake and prevents postischemic cardiac dysfunction, apoptosis, and injury. Journal of Clinical Investigation; 2004, 114 (4), pp 495-503. doi: 10.1172/JCI19297.

60. Mu, J.; Brozinick, J. T. Jr.; Valladares, O.; Bucan, M.; Birnbaum, M. J. A role for AMP-activated protein kinase in contraction- and hypoxia-regulated glucose transport in skeletal muscle. Molecular Cell; 2001, 7 (5), pp 1085-1094.

61. Marsin, A. S.; Bertrand, L.; Rider, M. H.; Deprez, J.; Beauloye, C.; Vincent, M. F.; Van den Berghe, G.; Carling, D.; Hue L. Phosphorylation and activation of heart PFK-2 by AMPK has a role in the stimulation of glycolysis during ischaemia. Current Biology; 2000, 10 (20), pp 1247-1255. 